GUSTAVO DOS REIS LEITÃO

\title{
O Plano de RECUPERAÇÃO JUdiCIAL E OS LiMiteS PARA A INTERVENÇÃo do PODER JUdiciário
}

DISSERTAÇÃO DE MESTRADO EM DIREITO COMERCIAL

\author{
Orientadora
}

Prof. Doutora Priscila Maria Pereira Corrêa da Fonseca

Departamento de Direito Comercial

Faculdade de Direito

Universidade de São Paulo

São Paulo, janeiro de 2019 


\section{GUSTAVO DOS REIS LEITÃO}

\section{O Plano de RECUPERAÇÃo JUdicial E OS LiMites PARA A INTERVENÇÃO DO PODER JUDICIÁRIO}

Dissertação apresentada à Banca Examinadora do Programa de Pós-Graduação em Direito, da Faculdade de Direito da Universidade de São Paulo, como exigência parcial para obtenção do título de Mestre em Direito, na área de concentração Direito Comercial, sob a orientação da Professora Doutora Priscila Maria Pereira Corrêa da Fonseca

UNIVERSIDADE DE SÃO PAULO

FACULDADE DE DIREITO

São Paulo - SP

2019 
Catalogação da Publicação

Serviço de Processos Técnicos da Biblioteca da

Faculdade de Direito da Universidade de São Paulo

Leitão, Gustavo dos Reis

O Plano de Recuperação Judicial e os Limites para a Intervenção do Poder Judiciário

Gustavo dos Reis Leitão - São Paulo - G. R. Leitão, 2019

Dissertação (Mestrado) - Universidade de São Paulo, 2019.

Orientador: Prof. Priscila M. P. Corrêa da Fonseca.

1. Recuperação Judicial. 2. Poder Judiciário. 3. Plano de recuperação judicial. I. Fonseca, Priscila M. P. Correa da, orient. II. Título. 


\section{Banca examinadora:}

1. Orientadora: Priscila M. P. Corrêa da Fonseca

2. Examinador(a):

3. Examinador(a): 

À Yasmin, pelo incentivo, ajuda, paciência, amor e amizade incondicionais.

Aos meus irmãos, Fábio e Maria Laura, pela alegria do convívio, pela inspiração e por nunca me deixarem desistir dos desafios. 



\section{AGRADECIMENTOS}

Este trabalho é uma mistura de sonho, desafio e persistência. Sem algumas pessoas essenciais, certamente, não seria concluído.

Agradeço à minha orientadora, Professora Priscila M. P. Corrêa da Fonseca, pela disponibilidade, atenção, auxílio e paciência. Pelos livros emprestados e pelas ajudas com as dúvidas e questionamentos.

À minha família, na figura dos meus pais, Milton e Débora, pelo apoio sempre presente.

À minha sogra, Lilian, pelos trabalhos de revisão de redação e português nas horas vagas, retomando o cargo de professora para me prestar auxílio.

Aos meus colegas de trabalho, especialmente, ao Felipe Evaristo dos Santos Galea, Igor Silva de Lima e Thomaz Luiz Sant'Ana pelas discussões e pela paciência com as minhas ideias e inquietações.

À minha Yasmin, por, além de topar um projeto de vida, aceitar os custos não financeiros do mestrado, sempre me apoiando.

A todos, o meu muitíssimo obrigado! 

Gustavo dos Reis Leitão. O Plano de Recuperação Judicial e os Limites para a Intervenção do Poder Judiciário. Janeiro de 2018. 128 folhas. Mestrado - Departamento de Direito Comercial, Faculdade de Direito, Universidade de São Paulo, São Paulo, 2019.

\section{RESUMO}

O presente trabalho tem por escopo a análise da conduta do Poder Judiciário diante do plano de recuperação judicial e dos limites para intervenção naquilo que foi pactuado entre devedor e seus credores. Com enfoque na jurisprudência do Tribunal de Justiça de São Paulo, busca-se analisar, na prática, como o Poder Judiciário se comporta perante os planos de recuperação judicial, bem como pontuar aquilo que já foi tido por ilegal no âmbito quando da análise de planos de recuperação judicial.

Palavras-chaves: recuperação judicial - poder judiciário - controle de legalidade - plano de recuperação judicial - concessão da recuperação judicial. 
Gustavo dos Reis Leitão. The judicial restructuring plan and the limits for a Court Revision. January 2018. 128 pages. Master degree - Corporate Law Department, Law School, University of São Paulo, São Paulo, 2019.

\begin{abstract}
The present study aims to analyze the behavior of the Court when deciding matters concerning the judicial restructuring plan, as well as the limitations to interfere with what has been negotiated between the debtor and its creditors. Focusing on Court decisions made by the State Court of São Paulo, this study seeks to analyze how the Court behaves towards the judicial restructuring plans and which situations have been considered illegal when judging the judicial restructuring plans.
\end{abstract}

Key-words: judicial restructuring - Court - Legality control - judicial restructuring plan - decision that granted the judicial restrucutring 


\section{ÍNDICE}

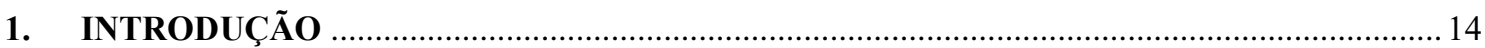

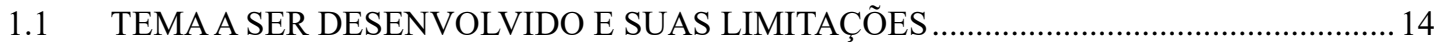

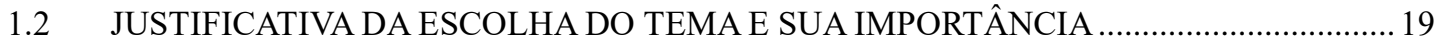

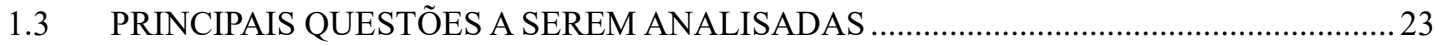

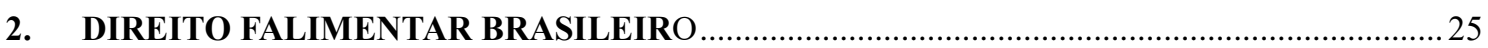

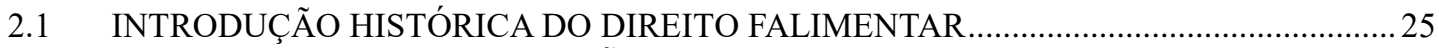

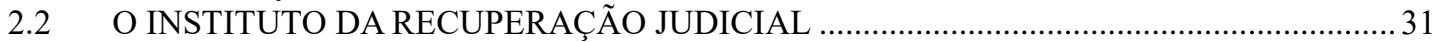

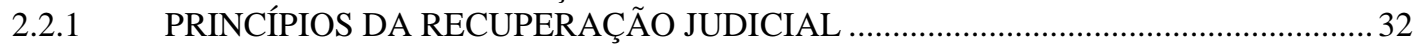

2.2.2.1 PRINCÍPIO DA PRESERVAÇÃO DA EMPRESA …………………………........... 33

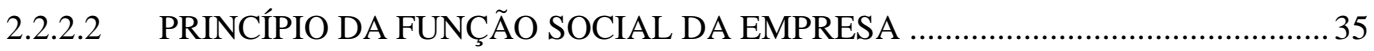

2.2.2.3 PRINCÍPIO DO “PAR CONDICIO CREDITORUM" ...................................................... 37

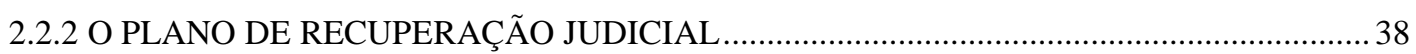

2.2.2.1 NATUREZA JURÍDICA DO PLANO DE RECUPERAÇÃO JUDICIAL ......................43

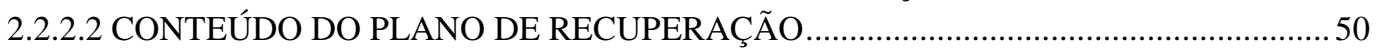

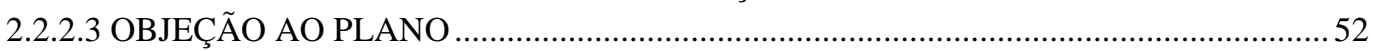

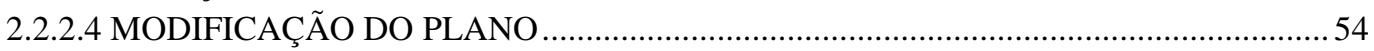

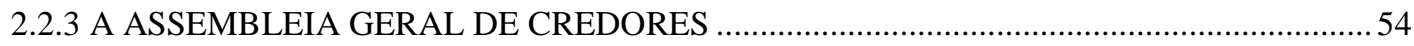

2.2.4 VOTAÇÃO E QUÓRUM PARA APROVAÇÃO DO PLANO .................................................56

3. CONTROLE JUDICIAL DO PLANO DE RECUPERAÇÃO JUDICIAL ........................................59

3.1. DECISÃO HOMOLOGATÓRIA DO PLANO DE RECUPERAÇÃO JUDICIAL APROVADO

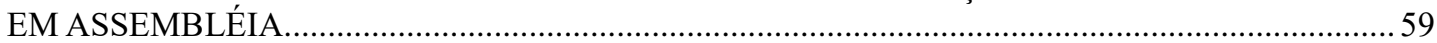

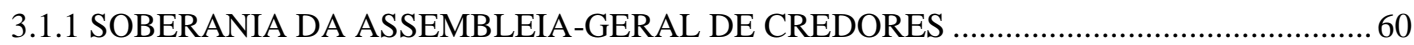

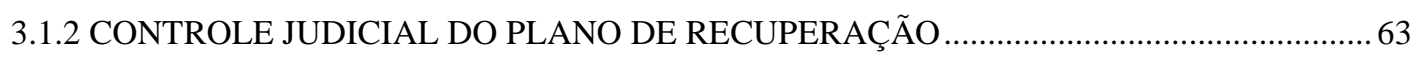

3.1.3 HIPÓTESES EM QUE SE JUSTIFICARIA O CONTROLE DE LEGALIDADE E A

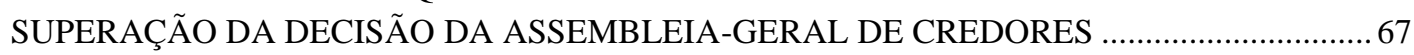

3.1.3.1 NULIDADE DE CLÁUSULA OU DO PRÓPRIO PLANO DE RECUPERAÇÃO

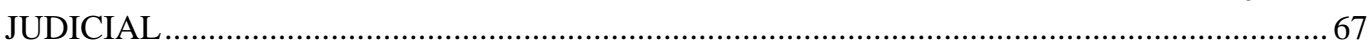

3.1.4.1 ABUSO DE DIREITO DE VOTO E CONFLITO DE INTERESSE ....................................6

3.1.5.1 "CRAM DOWN" OU A APROVAÇÃO ALTERNATIVA DO PLANO ………................. 78

3.2. CLÁUSULAS DO PLANO DE RECUPERAÇÃO JUDICIAL CONSIDERADAS ABUSIVAS 79

3.2.1 CONDIÇÕES DE PAGAMENTO: PRAZO DE PAGAMENTO, CARÊNCIA E DESÁGIO 80

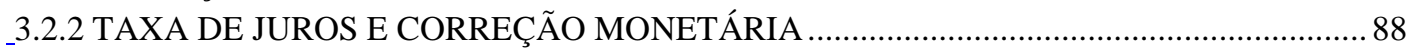

3.2.3 AUTORIZAÇÕES PARA ALIENAÇÃO DE ATIVOS E UNIDADES PRODUTIVAS

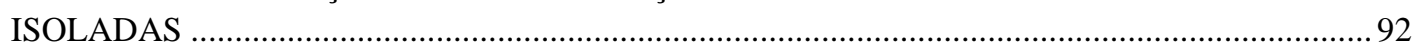

3.2.4 LIBERAÇÃO DE COOBRIGADOS, GARANTIDORES, GARANTIAS E EXTINÇÃO DE

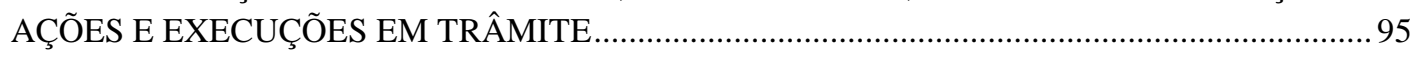

3.3.5 PERMISSÕES PARA A OBTENÇÃO DE NOVOS FINANCIAMENTOS …….....................99

3.3.6 CRIAÇÃO DE SUBCLASSES E CREDORES PARCEIROS ……..........................................99

4. LIMITES DE ATUAÇÃO DO PODER JUDICIÁRIO E CONSEQUÊNCIAS DA NÃO HOMOLOGAÇÃO DO PLANO DE RECUPERAÇÃo JUDICIAL APROVADO EM

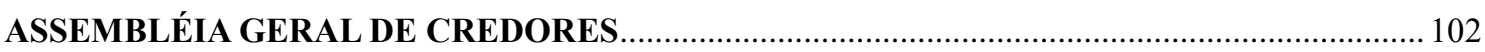

4.1 DISTINÇÃO ENTRE CONTROLE DE LEGALIDADE, JUIZO DE VIABILIDADE

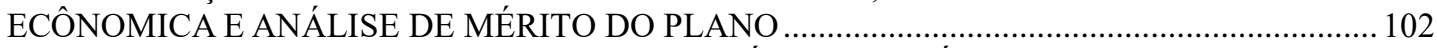

4.2 AUTONOMIA DA VONTADE PRIVADA E ANÁLISE DE MÉRITO DO PLANO....................... 104 
4.3 CONTROLE DE LEGALIDADE DO PLANO ENQUANTO CONTRATO JUDICIAL ......... 106

4.4. DECRETAÇÃO DE NULIDADE DO PLANO E SUAS CONSEQUÊNCIAS................................. 109

5. CONCLUSÃo E SUGESTÃo DE ALTERAÇÃO LEGISLATIVA PARA REGULAR O CONTROLE JUDICIAL DO PLANO DE RECUPERAÇÃO 112

6. BIBLIOGRAFIA 114 


\section{.}




\section{INTRODUÇ̃̃o}

\subsection{TEMA A SER DESENVOLVIDO E SUAS LIMITAÇÕES ${ }^{1}$}

A partir de um olhar realístico sobre o desempenho negativo da economia nacional, acreditamos ser pertinente, neste momento, nos debruçarmos sobre o tema escolhido - o plano de recuperação judicial e os limites para a intervenção do Poder Judiciário -, uma vez que há uma crescente utilização da recuperação judicial no país desde 2015.

A relevância de tal estudo não se apoia somente em razão da incidência ampla da recuperação judicial em decorrência do contexto econômico do país, mas também no âmbito científico, visto que devemos analisar criticamente aspectos da Lei n. 11.101/2005 bem como a doutrina e a jurisprudência referentes ao tema proposto. Afinal estamos tratando de um instituto muito utilizado recentemente e que causa impactos não só na empresa em crise, mas em toda a sociedade.

Como sabemos, o direito falimentar está ligado à evolução do próprio conceito de obrigação. Na origem, o direito se limitava a punir o devedor falido com penas que poderiam representar a perda de sua liberdade ou mesmo de sua própria vida, ignorando, assim, os efeitos reflexos que a quebra causa na economia, na sociedade e, também, os direitos fundamentais e humanos daquele que exercia a atividade empresarial.

Passados séculos, com a evolução do conceito de obrigação, o processo falimentar também, consequentemente, evoluiu, pois, o direito entende que o estado de insolvência nada mais é do que a impossibilidade total de adimplemento das obrigações da empresa, justificando sua liquidação.

No Brasil, a evolução do direito falimentar não foi distinta de outras jurisdições. Legislação após legislação, o direito falimentar brasileiro foi evoluindo, arriscamos dizer, a passos lentos. Do Brasil Colônia, passando pela proclamação da República em 1889, até o presente, diversas legislações sobre o tema. Inicialmente, também se objetivou punir o comerciante falido, todavia, com o passar do tempo, as leis brasileiras foram se modernizando

\footnotetext{
${ }^{1}$ Este trabalho foi elaborado de acordo com as regras de metodologia contidas em E. C. SILVEIRA MARCHI, Guia de metodologia jurídica - teses monografias e artigos, $2^{a}$ ed., São Paulo, Saraiva, 2009, passim. As citações bibliográficas serão realizadas de acordo com o modelo franco-italiano, ressalvando-se que alguns juristas pátrios serão referidos pelo prenome por extenso sempre que assim forem conhecidos na comunidade jurídicocientífica.
} 
até reconhecerem a função social da empresa e passarem a buscar a preservação das atividades econômicas viáveis.

É justamente nesse sentido que a Lei n. 11.101/2005, a mais recente experiência legislativa brasileira, foi sancionada, alterando o paradigma do direito comercial e falimentar brasileiro, ao contemplar o novo conceito de empresa trazido pelo Código Civil de 2002 e a função social da empresa, instituída pela Constituição Federal de 1988.

O legislador, reconhecendo a importância da manutenção da atividade econômica da empresa para a geração de empregos, de recursos e o recolhimento de impostos, deixou de ter como preocupação central a liquidação de $\operatorname{ativos}^{2}$, com a retirada da empresa do mercado, para criar uma ferramenta legal, objetivando a superação da crise empresarial.

Logo, a principal inovação trazida pela Lei n. 11.101/2005 foi a incorporação do instituto da recuperação ao Direito Brasileiro, lastreado no princípio da preservação da empresa, propondo-se a utilização de duas medidas legais para se buscar a superação da crise econômicofinanceira: a recuperação judicial e a extrajudicial.

Em razão da inexpressiva utilização do instituto da recuperação extrajudicial no Direito Brasileiro, optamos por fazer uma delimitação no tema da dissertação de mestrado pretendida, enfocando tão somente o instituto da recuperação judicial.

Dessa forma, acreditamos que o trabalho a ser realizado propiciará importante contribuição nas discussões sobre o tema, mostrando-se viável sua investigação.

Estudaremos a caracterização da recuperação judicial como instituto genérico, para comprovarmos se, de fato, é uma de suas marcas mais adequadas, visto que o legislador, em

\footnotetext{
${ }^{2}$ Muito embora entenda-se possível a verificação do princípio da preservação da empresa também na falência. Nesse sentido: "É possível afirmar, assim, que uma das finalidades da falência é a de promover uma transição de titularidade dos bens organizados que integram o estabelecimento do devedor para um novo titular, que dará continuidade ao business, preservando a empresa. Essa transição, portanto, tem a dúplice finalidade: melhor atender aos interesses dos credores (maximizando o valor de venda dos ativos), além de preservar e otimizar a utilização produtiva dos bens". CAMPOS SALLES, Paulo Fernando; e, PUGLIESI, Adriana V. Tratado de Direito Empresarial, volume V: Recuperação Empresarial e Falência. Coordenação CARVALHOSA, Modesto. São Paulo: Revista dos Tribunais, 2016, p. 269

No mesmo sentido: "Art. 75. A falência, ao promover o afastamento do devedor de suas atividades, visa a preservar e otimizar a utilização produtiva dos bens, ativos e recursos produtivos, inclusive os intangiveis, da empresa.

(...)

Art. 139. Logo após a arrecadação dos bens, com a juntada do respectivo auto ao processo de falência, será iniciada a realização do ativo".
} 
vez de adotar medidas específicas para empresas em determinadas situações, optou, por meio da nova lei, em seu artigo 50, por estabelecer um rol não taxativo de medidas de recuperação que a empresa em crise poderá vir a adotar.

Desse modo, independentemente da área de atuação ou da atividade empresarial desenvolvida, o instituto da recuperação judicial é hábil para salvaguardar qualquer empresa em crise, permitindo que esta apresente uma proposta de um plano de recuperação viável e específico para o saneamento de suas dificuldades financeiras pautado no resultado da análise interna de seus problemas efetuado pela por ela mesma.

Esse plano de recuperação, ponto principal de nossa investigação, consiste em verdadeiro acordo de vontades entre a recuperanda e seus credores. Para tanto, cabe à devedora apresentar seu plano de recuperação que será objeto de apreciação dos credores e deverá ser votado quando da realização da assembleia-geral de credores. Caso seja aprovado, passa, então, a produzir efeitos apenas para os créditos sujeitos à recuperação judicial.

Avaliaremos os efeitos da Lei n. 11.101/2005 que não dispõe sobre como deve ser o conteúdo do plano de recuperação, podendo cada empresa tomar as medidas e propor as soluções que entenda necessárias para a solução de sua crise empresarial.

Assim, o plano de recuperação judicial deverá contemplar os meios que a empresa adotará para se recuperar e pagar suas dívidas, incluindo, neste requisito, a forma e o prazo de pagamento dos credores. Além disso, deve conter um laudo indicando sua viabilidade econômica e um laudo financeiro de avaliação de bens e ativos do devedor, ambos assinados por empresa ou profissional capacitado.

Para que o plano de recuperação judicial seja aprovado, nesses casos, é necessário que o voto dos credores seja a ele favorável. Durante a votação, os credores são divididos em quatro classes: trabalhista, quirografária, com garantia real e microempresários/empresários de pequeno porte, sendo necessária a aprovação do plano em todas as classes. Há, todavia, critérios distintos de votação entre elas.

Dispõe o artigo 58 da Lei 11.101/2005, que, cumpridos os requisitos legais, caberá ao juiz a concessão da recuperação judicial do devedor caso o plano de recuperação judicial não tenha sofrido objeção ou no caso de aprovação do plano pela assembleia-geral de credores. 
Em outras palavras, para a empresa ser considerada em recuperação judicial não basta a aprovação dos seus credores, ainda que tácita. Prevê a lei, de forma expressa, a participação do juiz de direito, a quem compete conceder, por meio de decisão judicial, a recuperação judicial.

Diante disso, nasce a discussão, tema chave do presente trabalho, acerca de do papel do Poder Judiciário quando da homologação do plano de recuperação judicial e os limites de sua atuação.

Após a edição da Lei n. 11.101/2005, partindo de uma interpretação estritamente gramatical do artigo 58, desenvolveu-se a tese de que a assembleia-geral de credores seria totalmente soberana para tratar das cláusulas do plano de recuperação judicial.

Assim, os credores e os devedores, no exercício total e pleno de sua autonomia contratual, estariam apenas negociando seu direito patrimonial disponível durante o processo, culminando com realização da assembleia-geral de credores, cabendo ao juiz papel meramente homologatório, respeitando o teor das tratativas e a vontade manifesta dos envolvidos.

Nesse sentido, um dos argumentos sustentadores da referida tese se baseava no fato de que se utilizou na lei o verbo "concederá", remetendo a uma ideia de que, caso o plano de recuperação judicial tenha obtido a aprovação dos credores, tem o juiz o dever de homologá-lo para que produza efeitos.

Logo, por essa construção doutrinária, cumprindo-se os requisitos legais, a recuperação judicial seria uma espécie de direito do devedor em crise, uma vez que este já obteve êxito na negociação com seus credores.

Evidentemente que, para um plano de recuperação judicial cumprir com os requisitos da Lei n. 11.101/2005, não poderá conter previsões ilegais ou violadoras de matéria de ordem de pública. Em outras palavras, realizando uma releitura da referida tese, embora na época a discussão doutrinária ignorasse quase por completo a possibilidade de intervenção judiciária, prestigiando a soberania da decisão dos credores em assembleia-geral, jamais se afirmou categoricamente ou vedou-se o controle judicial do plano de recuperação.

Contudo, a ausência de controle judicial do plano de recuperação gerou inúmeros e incontáveis abusos, favorecendo fraudes, aplicados com a homologação, ou seja, com a ratificação do Poder Judiciário. 
Verificamos que a Lei n. 11.101/2005, apesar da qualidade do diploma legal, passou enfrentar o mesmo problema que as antigas e já revogadas leis falimentares também sofreram, mostrando que, apesar de uma mudança legislativa, as más práticas jurídicas persistiam, impedindo o novo diploma legislativo de cumprir com o seu objetivo.

Diante dessa situação fática que se delineava, estudaremos posição doutrinária que defende a possibilidade de o Poder Judiciário deixar de homologar o plano de recuperação judicial, mesmo se aprovado em assembleia geral de credores, quando este tivesse alguma disposição ilegal que violasse matéria de ordem pública.

O controle judicial do plano de recuperação judicial se consolidou quando o Tribunal de Justiça de São Paulo, em 28.2.2012, proferiu decisão inédita, de relatoria do Desembargador Manoel de Queiroz Pereira Calças, nos autos do agravo de instrumento n. 013636229.2011.8.26.0000, deixando de homologar o plano de recuperação judicial apresentado pela Cerâmica Gyotoku Ltda. por entender que a proposta, apesar de aprovada e assembleia-geral de credores, continha cláusulas ilegais e violadoras da ordem pública.

Analisaremos, assim, o entendimento de que a soberania da assembleia-geral de credores estaria condicionada ao cumprimento dos dispositivos da Constituição Federal e da legislação vigente, especialmente, em relação aos trâmites e procedimentos previstos na Lei n. 11.101/2005. Desde então, a jurisprudência brasileira vem consolidando o entendimento de que o Poder Judiciário pode intervir no plano de recuperação judicial aprovado pela assembleiageral de credores, exercendo controle de legalidade.

Diante de duas posições distintas, que privilegiam tanto o controle judicial quanto a soberania da assembleia-geral de credores, de um posicionamento jurisprudencial que evoluiu conjuntamente com a Lei n. 11.101/2005 e suas discussões doutrinárias, este projeto de dissertação visa justamente estudar os limites e como se deve dar a intervenção e o controle de legalidade do plano de recuperação judicial pelo Poder Judiciário, bem como dos comportamentos, condutas e motivações que levaram à sua aprovação ou rejeição.

Além de analisar as duas correntes, este estudo tem também por objetivo verificar os planos e as cláusulas que já foram consideradas nulas, ilegais e violadoras da ordem pública, para concluir quais são os fundamentos motivadores de tais decisões, a fim de buscar critérios que permitam definir o que é ou não permitindo no plano de recuperação judicial e no ambiente de sua negociação. 
Diante da exposição acerca da relevância do estudo do tema, acreditamos ser possível, ao final do estudo apresentarmos um resultado de pesquisa significativo e levantarmos importantes reflexões sobre a recuperação judicial e seus desdobramentos no contexto econômico nacional.

\subsection{JUSTIFICATIVA DA ESCOLHA DO TEMA E SUA IMPORTÂNCIA}

Como adiantado no tópico precedente, o tema relativo ao controle judicial do plano de recuperação judicial, bem como os limites dessa intervenção é recorrente nos debates jurídicos diante da crescente popularização e utilização do instituto da recuperação judicial. ,

Podemos confirmar tal afirmação, de acordo o indicador econômico Serasa Experian de Falências e Recuperações Judiciais, ${ }^{3}$ abaixo, que, ano após ano, o número de recuperações judiciais requeridas e concedidas cresce no país ${ }^{4}$ :

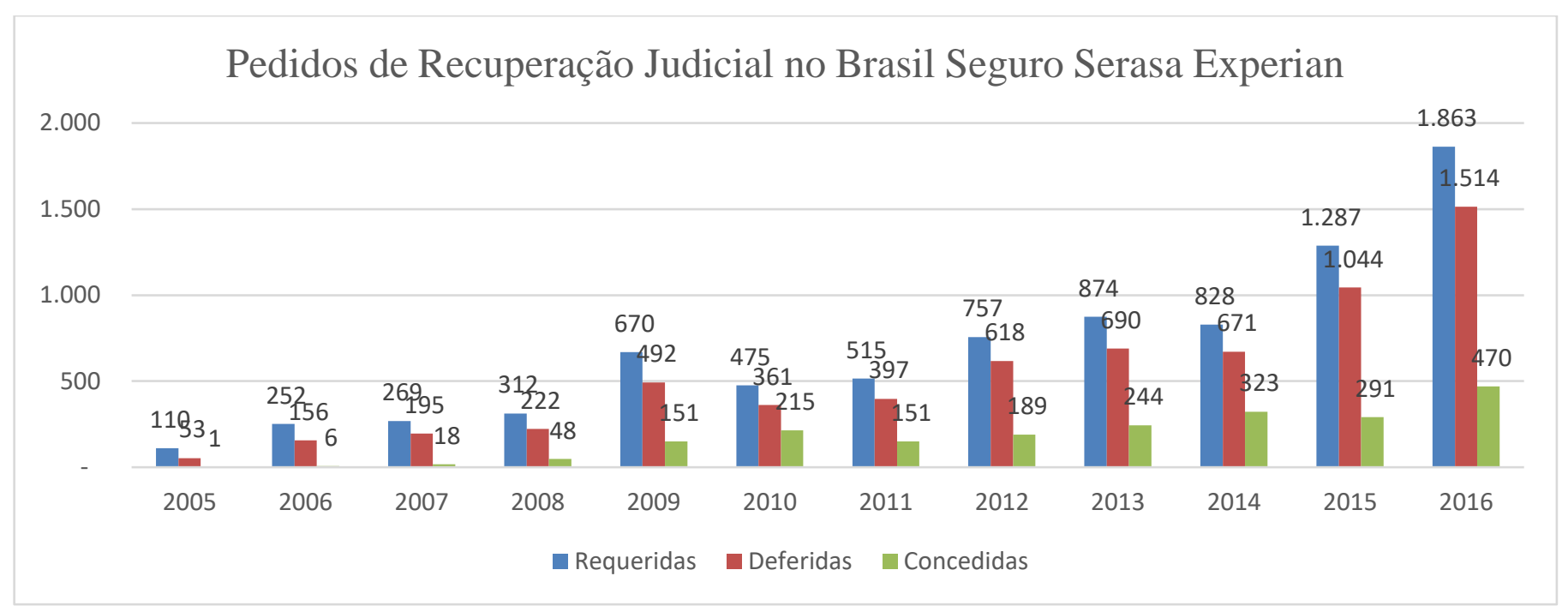

Em 2015, ano de crise econômica e de recessão da economia brasileira, foram um mil, duzentos e oitenta e sete (1.287) recuperações judiciais requeridas, das quais um mil e quarenta e quatro (1.044) foram deferidas. No igual período de 2014, houve oitocentos e setenta e quatro (874) recuperações judiciais requeridas e seiscentos e noventa (690) deferidas.

${ }^{3}$ Disponível em http://www.serasaexperian.com.br/release/indicadores/falencias_concordatas.htm [acesso em 4.7.2017].

${ }^{4}$ Gráfico elaborado com os dados do indicador econômico Serasa Experian de Falência e Recuperações Judiciais, disponível em http://www.serasaexperian.com.br/release/indicadores/falencias concordatas.htm [acesso em 4.7.2017]. 
Todavia, em 2016, o referido número bateu a então a série histórica de 2015 com o deferimento de um mil, quinhentos e quatorze (1.514) recuperações judiciais deferidas de um total de um mil oitocentos e sessenta e três $(1.863)$ requeridas.

$\mathrm{Na}$ mesma direção, apontam os resultados obtidos pelo trabalho desenvolvido pelo Núcleo de Estudo e Pesquisa sobre Insolvência da Pontifícia Universidade Católica de São Paulo ${ }^{5}$. Observemos o gráfico abaixo.

\section{$\%$ DE DEFERIMENTOS}

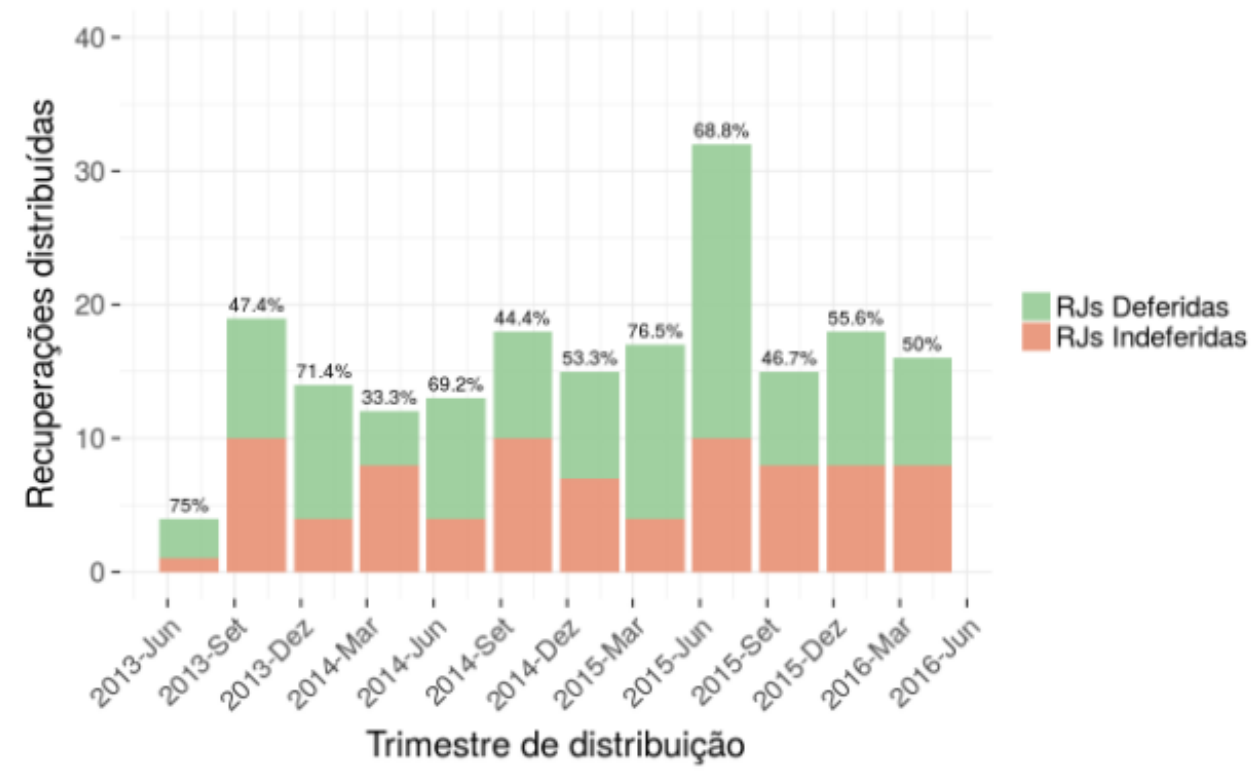

Ainda para justificar a importância e relevância do tema escolhido apresentamos, a seguir, o trabalho desenvolvido pelo economista e jurista Rafael Bianchini Abreu Paiva ${ }^{6}$ para uma das aulas do curso de pós-graduação desta faculdade e deste departamento de direito comercial, no primeiro semestre de 2017 sobre a correlação do crescimento do PIB (produto interno bruto) do Brasil com os pedidos de recuperação judicial. Analisemos o gráfico.

\footnotetext{
${ }^{5}$ Disponível em http://rpubs.com/abj/pucrj pre [acesso em 2.1.2019].

${ }^{6}$ Gráfico elaborado com os dados do indicador econômico Serasa Experian de Falência e Recuperações Judiciais e do IBGE, conforme conclusões disponíveis em https://bianchini.blog/2016/11/01/notas-sobre-o-ciclo-de-endividamento-do-setorprivado-nao-financeiro/ [acesso em 2.1.2019].
} 


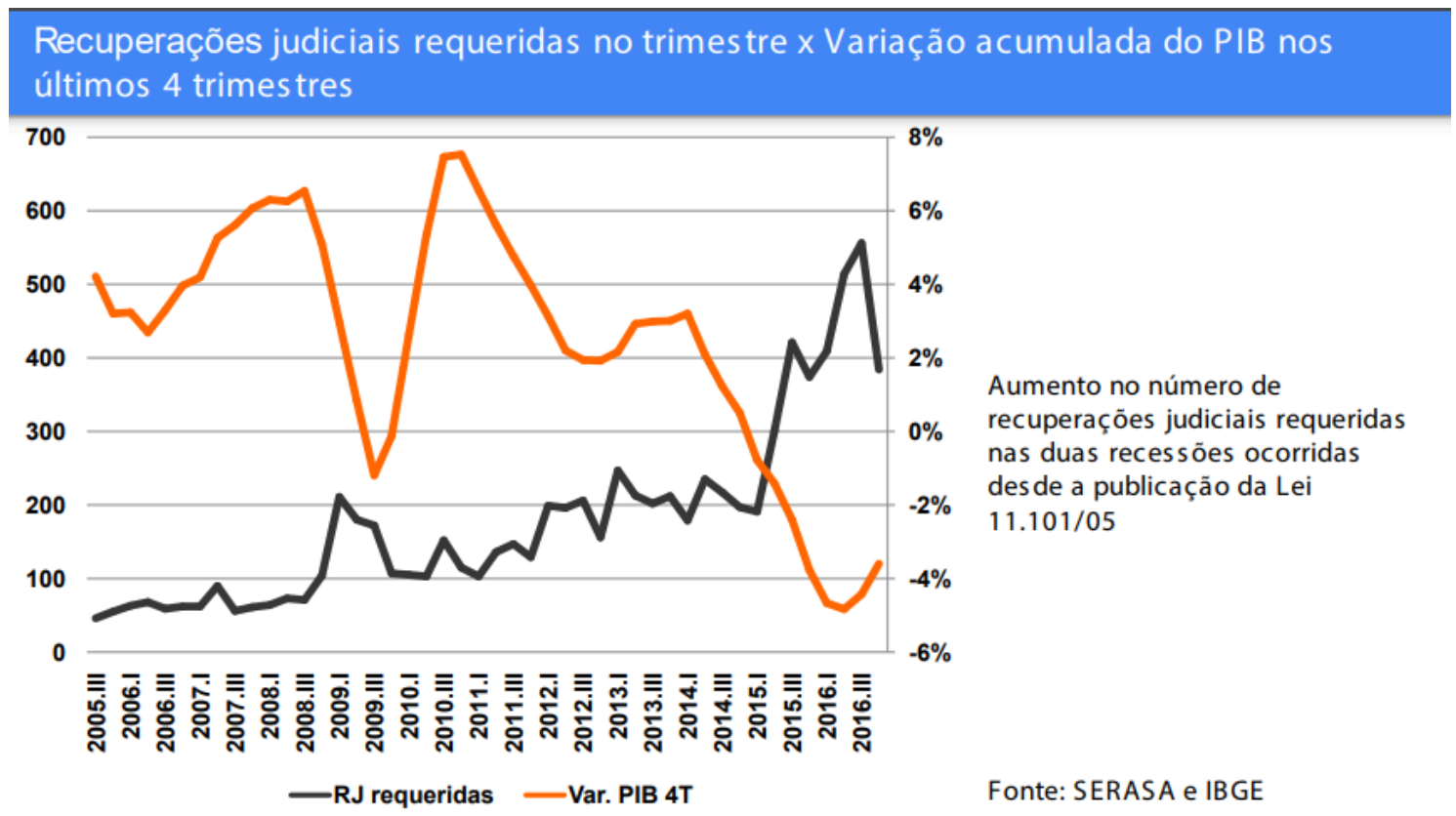

Como podemos averiguar, os estudos que destacamos acima confirmam a crescente utilização da recuperação judicial diante da crise econômica que se instalou no país. Enquanto o PIB (produto interno bruto) do Brasil teve uma queda durante o período de crise econômica, o número de recuperação judicial requeridas, consequentemente, cresceu. Logo há que se debruçar sobre o tema, verificando-se os aspectos da Lei n. 11.101/2005.

Acreditamos que a Lei n. 11.101/2005 seja um instrumento legislativo hábil para auxiliar as empresas e os empresários do país a superarem estes períodos de crise. Contudo torna-se cada vez mais necessário saber quais os limites das negociações do plano de recuperação judicial e até que ponto o Poder Judiciário, no exercício do seu poder-dever de justiça, pode e deve intervir nas negociações entre credores e devedores, consubstanciadas no plano de recuperação judicial e nas deliberações tomadas em assembleia-geral de credores.

Da mesma forma, é importante realizar uma análise da jurisprudência para identificar quais cláusulas dos planos de recuperação judicial já foram consideradas nulas e/ou ilegais, bem como analisar a fundamentação destas decisões, a fim de se estabelecer um padrão e depreender limites para a autonomia da vontade de credores e recuperandas.

A importância do referido trabalho está ligada à importância da preservação da atividade empresarial e consequente manutenção da fonte geradora de empregos, receitas e recolhimento de tributos, privilegiando a função social da empresa. 
Não há dúvidas de que o processo de recuperação judicial é meio pelo qual se busca a proteção judicial e legal para a preservação da empresa. E, como todo o processo de recuperação judicial caminha para novação das dívidas das recuperandas e elaboração de um acordo do devedor com seus credores, nas mais variadas classes, torna-se essencial estudar não apenas o plano de recuperação judicial, como também o tratamento despendido com ele pelo Poder Judiciário.

A invalidade de cláusulas ou de todo o plano de recuperação judicial pode certamente comprometer toda a reestruturação proposta pela empresa, o que comprometeria a preservação da atividade econômica.

Além disso, há uma nítida questão de segurança jurídica que impõe tal estudo. Afinal, quando credores, devedores e potenciais investidores estão negociando um plano de recuperação judicial, torna-se necessário saber se o plano decorrente das rodadas de negociação será exequível perante a lei brasileira, bem como os limites do Poder Judiciário na autonomia dos envolvidos na negociação.

Notemos que, diferentemente de outros tipos de acordos, o plano de recuperação judicial pressupõe a imposição de uma reestruturação de dívida a uma minoria pela maioria, que não necessariamente anuiu ou mesmo concordou com os referidos termos. Estabelecer as regras deste jogo torna-se simplesmente essencial para o sucesso da utilização do instituto da recuperação judicial.

Na prática, observamos que não são raros os casos em que a homologação do plano de recuperação fica suspensa ou sem efeito por conta de liminar judicial. Evidentemente, que as liminares judiciais continuarão a existir. Contudo, ao entendermos os limites e as regras da intervenção pelo Poder Judiciário na recuperação judicial, criamos segurança jurídica para as reestruturações. Dessa forma, tal estudo, ao nosso ver, se faz imprescindível e urgente.

Ademais, o referido tema é inclusive alvo de discussões pelo Poder Legislativo, o que, também, corrobora para a justificativa de seu estudo e sua importância. Pelo Projeto de Lei do Senado $n^{\circ} 391$ de $2009^{7}$, pretende-se alterar a Lei n. 11.101/2005 para que os credores possam alterar livremente o plano de recuperação judicial na assembleia-geral de credores, de tal modo que a concordância das alterações pelo devedor poderá ser suprida por decisão judicial. Na justificativa do referido projeto, depreendemos que o legislador buscar inibir o veto abusivo 
dos devedores nas propostas de alteração do plano em assembleia-geral de credores, muitas vezes, contrário até mesmo aos demais interesses em jogo no processo de recuperação judicial.

Já o Projeto de Lei do Senado n 140 de $2011^{8}$, busca melhor regular o procedimento da assembleia-geral de credores para determinar que após as discussões, serão formalizadas as propostas de aprovação, modificação ou rejeição do plano de recuperação judicial. A justificativa é a de que a assembleia-geral de credores [e o plano de recuperação] têm sido foco de dúvidas. A lei visa criar um procedimento para que haja uma construção conjunta do plano de recuperação judicial por credores e devedores, de modo que "todos os credores opinem e proponham modificações dentro da cota sacrífico que cada um está disposto a aceitar a falência de empreendimentos que ainda podem ser viáveis"9.

Portanto, diante de todo exposto, fica justificada a escolha do tema, bem como o motivo do referido estudo e sua importância para o direito falimentar e comercial brasileiro.

\subsection{PRINCIPAIS QUESTÕES A SEREM ANALISADAS}

No estudo cujo projeto é ora apresentado, procuraremos analisar o dever e a possibilidade de intervenção do Poder Judiciário no plano de recuperação judicial, com enfoque em cláusulas e nos métodos de recuperação que já foram considerados nulos ou ilegais pela jurisprudência.

Para tanto, utilizaremos os seguintes objetivos específicos:

1. Examinar a evolução histórica do direito falimentar, com foco principalmente na evolução legislativa brasileira.

2. Analisar a relação entre o histórico de mudanças legislativas no âmbito do direito falimentar e a busca por procedimentos mais transparentes e com menos tentativas de abusos e fraudes.

3. Investigar o status atual de formação, propositura e negociação do plano de recuperação judicial. Averiguar a aplicação prática desse sistema, investigando suas limitações e progressos. Ainda, investigar a formação do modelo atual a fim de confirmar a existência ou não de uma

${ }^{8}$ Disponível em http://www25.senado.leg.br/web/atividade/materias/-/materia/93020 [acesso em 9.7.2017.

${ }^{9}$ Disponível em http://www.senado.leg.br/atividade/rotinas/materia/getPDF.asp?t=88567\&tp=1 [acesso em 9.7.2017. 
cultura de cooperação entre os sujeitos do plano de recuperação judicial, isto é, entre credores e recuperanda.

4. Investigar a natureza jurídica do plano de recuperação judicial. Verificar o limite do poder de disposição dos direitos disponíveis das partes, bem como o limite da autonomia da vontade das partes, considerando o maior poder de decisão e pressão atribuído aos credores com maior crédito.

5. Investigar os julgados envolvendo controle de legalidade pelo Poder Judiciário do plano de recuperação judicial. Verificar quais as cláusulas comumente utilizadas que já foram consideradas nulas. Verificar o motivo alegado pelos tribunais, bem como a fundamentação utilizada. 


\section{CONCLUSÃO E SUGESTÃO DE ALTERAÇÃO LEGISLATIVA PARA $\begin{array}{lllllll}\text { REGULAR O CONTROLE JUDICIAL DO PLANO DE } & \text { O }\end{array}$ RECUPERAÇÃO}

Após todo o trabalho, verificamos que o paradigma jurisprudencial do controle de legalidade foi alterado recentemente no Brasil e ainda está constante alteração.

Como visto, inicialmente, os tribunais buscavam respeitar o pactuado entre credores e devedores, quase sem exercer qualquer controle de legalidade. Posteriormente, houve uma mudança no entendimento e o controle de legalidade passou a ser realizado de maneira ostensiva, acabando por adentrar em questões inerentes a viabilidade econômica e do mérito do plano, propriamente dito.

Atualmente, sem qualquer dúvida, não mais se reconhece a assembleia-geral de credores como absolutamente soberana.

O Poder Judiciário vem rotineiramente efetuado o controle de legalidade dos planos. Como exposto nos capítulos específicos, há entendimentos pacificados sobre diversas cláusulas que rotineiramente são apresentadas nos planos e que não são aceitas pelo Tribunal de Justiça de São Paulo. Ademais, busca-se verificar questões de legalidade, sem muita interferência no conteúdo econômico do plano.

Por isto, não é incomum a declaração de nulidade de diversos planos de recuperação judicial.

Mesmo assim, ainda não parece claro, na pesquisa empírica, que os tribunais conseguem restringir totalmente os limites de sua atuação, identificando de forma aquilo que deve ser analisado via controle de legalidade e o que é efetivamente parte do conteúdo econômico do plano.

Controle de legalidade, como o próprio nome sugere, deve ser buscar analisar a legalidade das disposições, mas sem adentrar no mérito do plano, isto é, compor um juízo de valor subjetivo sobre o meio e a forma escolhida para a superação da crise, ou mesmo sobre a viabilidade ou não do plano e da empresa.

Também não se deve verificar a possibilidade de a empresa em recuperação judicial cumprir com a referida avença, o que cabe, exclusivamente, aos credores. 
Conforme observamos neste trabalho, as lacunas existentes na Lei n. 11.101/2005 acabam prejudicar o bom desenvolvimento da recuperação judicial no país, trazendo como consequências, algumas interpretações equivocadas da lei que acabam por impedir um maior grau de recuperação judicial das empresas.

Para solucionar este problema, propomos que o art. 58 da Lei n. 11.101/2005 seja alterado, com a inclusão de três parágrafos com a seguinte redação:

$\S 2^{\circ}$. A análise de viabilidade econômica do plano de recuperação judicial é de exclusiva competência dos credores, reunidos em assembleia-geral de credores.

$\S 3^{\circ}$. Ao conceder a recuperação judicial, o juiz apenas poderá efetuar o controle de legalidade estrita do plano nos termos do art. 166. do Código Civil para coibir eventuais ilegalidades a legislação vigente.

Por fim, entendemos que este posicionamento resguarda de forma ampla os valores da Lei n. 11.101/2005, inibindo a prática de fraudes e garantido vida longa ao dispositivo legal. 


\section{BIBLIOGRAFIA}

ALMEIDA, Amador Paes de. Curso de Falência e Concordata. 19a ed. rev. e atual, São Paulo: Saraiva, 2001.

ANDREY, Marcos. Comentários à nova Lei de Recuperação de Empresas e Falências. Coordenação DE LUCCA, Newton e SIMÃO FILHO, Adalberto, São Paulo: Quartier Latin, 2005.

AYOUB, Luiz Roberto, e, CAVALLI, Cássio. A Construção Jurisprudencial da Recuperação Judicial de Empresas. 2ª Edição. Rio de Janeiro: Forense, 2016.

BANDEIRA DE MELLO, Celso Antônio. Curso de Direito Administrativo. 27a . ed., São Paulo; Malheiros, 2010.

BARBI, Celso Agrícola, Os poderes do juiz e a reforma do Código de processo civil, in Revista Forense n. 730/732 (1964), pp. 13-19.

BASTOS, Celso Ribeiro. Curso de Direito Constitucional. 16a . ed., São Paulo; Saraiva; 1995.

BAUR, Fritz, O papel ativo do juiz, in Revista de Processo n. 27, (1982) pp. 186-199

BEZERRA FILHO, Manoel Justino. Jurisprudência da Nova Lei de Recuperação de Empresas e Falência. São Paulo: Revista dos Tribunais, 2006.

BEZERRA FILHO, Manoel Justino. Lei de recuperação de empresas e falência: Lei 11.101/2005: comentada artigo por artigo. $7^{\mathrm{a}}$ ed. rev., atual. e ampl., São Paulo: Revista dos Tribunais, 2017.

BRANCO, Gerson Luiz Carlos. O poder dos Credores e o Poder do Juiz na Falência e na Recuperação Judicial. in Revista dos Tribunais, vol. 936, ano 2013. P. 43.

BUSCHINELLI, Gabriel Saad Kik. Abuso do Direito de Voto na Assembleia Geral de Credores. São Paulo: Quartier Latin, 2014. 
CAMPINHO, Sérgio. Falência e Recuperação de Empresas: o novo regime de insolvência empresarial. São Paulo: Renovar, 2016.

CAMPINHO, Sérgio. Curso de direito comercial: falência e recuperação de empresas. $8^{\mathrm{a}}$ ed. São Paulo: Saraiva, 2017

CAMPILONGO, Celso Fernandes, O judiciário e a democracia no Brasil, in Revista USP n. 21 (1994), pp. 117-125.

CAMPILONGO, Celso Fernandes, Política, sistema jurídico e decisão judicial, São Paulo, Max Limonad, 2002.

COELHO, Fábio Ulhoa. Comentário à nova lei de falência e de recuperação judicial (Lei $n$. 11.101, de 9-2-2005). 6ª ed., São Paulo: Saraiva, 2016.

COELHO, Fábio Ulhoa (Coordenação). Tratado de Direito Comercial: Falência e Recuperação de Empresas. Direito Marítimo. São Paulo: Saraiva, 2015.

CORREA-LIMA, Osmar Brina e CORREA-LIMA, Sérgio Mourão, coordenadores. Comentários à nova lei de falências e de Recuperação de Empresas, Rio de Janeiro, Ed. Forense, 2009.

CARVALHO DE MENDONÇA, José Xavier. Tratado de Direito Comercial.: Volume VII, Livro V. $5^{\text {a }}$ Edição. Livraria Freitas Bastos: São Paulo, 1954

DAVID ARAUJO, Luiz Alberto, e, SERRANO, Vidal. Curso de Direito Constitucional. 14 ${ }^{\mathrm{a}}$ ed., São Paulo; Saraiva, 2010.

DE LUCCA, Newton, Teoria Geral, in Comentários à nova Lei de Recuperação de Empresas e Falências, Newton de Lucca e Adalberto Simão Filho, coordenadores, Quartin Latin, São Paulo, 2005. 
FERREIRA, Waldemar. Instituições de Direito Comercial, Quinto Volume: A Falência Quarta Edição. Max Limonad: São Paulo, 1955.

FONSECA, Priscila Maria Pereira Corrêa da. Suspensão de deliberações sociais. São Paulo: Saraiva, 1986.

FINKELSTEIN, Cláudio. Direito internacional: seus tribunais e meios de solução de conflitos. coordenação de ARANA, Josycler, e CACHAPUZ, Rozane da Rosa, Curitiba, Juruá, 2007.

FRANCO, Vera Helena de Mello e SZTAJN, Raquel. Falência e recuperação de empresas. Rio de Janeiro: Elsevier/Campus, 2008.

GRAU, Eros Roberto. A ordem econômica na Constituição de 1988. $4^{\mathrm{a}}$ ed., São Paulo; Malheiros, 1998.

KIRSCHBAUM, Deborah. Recuperação Judicial no Brasil: Governança, Financiamento Extraconcursal e Votação do Plano de Recuperação Judicial. São Paulo: Novas Edições Acadêmicas, 2009.

LOBO, Jorge. Comentários à Lei de Recuperação de Empresa e Falência. Coordenação TOLEDO, Paulo F. C. Salles, e ABRÃO, Carlos Henrique, São Paulo: Saraiva, 2005.

MACHADO, Rubens Approbato. Comentários à Nova Lei de Falências e Recuperação de Empresas: doutrina e prática. Rio de Janeiro: Quartier Latin, 2005.

MAMEDE, Gladston. Direito empresarial brasileiro: falência e recuperação de empresas, volume 4. $5^{\mathrm{a}}$ ed., São Paulo: Atlas, 2012.

MANDEL, Julio Kahan. Nova lei de falências e recuperação de empresas anotada. $1^{\mathrm{a}}$. ed, São Paulo: Saraiva, 2005.

MUJALLI, Walter Brasil. Manual Prático e Teórico da Falência e Concordata. $1^{\mathrm{a}}$ ed., São Paulo: Liv. e Ed. Universitária de Direito, 1999. 
MUNHOZ, Eduardo Secchi. Comentários à Lei de Recuperação de Empresas e Falência. Coordenação SATIRO, Francisco, e, MORAES PITOMBO, Antônio Sergio A. de, $2^{\text {a }}$ ed., ver., atual., e ampl., São Paulo: Revista dos Tribunais, 2007.

MUNHOZ, Eduardo Secchi. Anotações sobre os Limites do Poder Jurisdicional na Apreciação do Plano de Recuperação Judicia, in Revista de Direito Bancário e do Mercado de Capitais, vol. 36. Revista dos Tribunais: São Paulo, 2007.

MELO, Cinira Gomes Lima. O plano de recuperação judicial como negócio jurídico plurilateral: a análise da existência, da validade e da eficácia. Tese (Doutorado em Direito). Pontifícia Universidade Católica de São Paulo, 2016.

NEDER CEREZETTI, Sheila Christina. A recuperação judicial de Sociedade por Ações. $O$ princípio da preservação da Empresa na Lei de Recuperação e Falência. $1^{\mathrm{a}}$ edição, São Paulo: Malheiros, 2012.

NEGRÃO, Ricardo. Aspectos Objetivos da Lei de Recuperação de Empresas e de Falência. $2^{a}$ edição. São Paulo: Saraiva, 2008.

NEGRÃO, Ricardo. Curso de Direito Comercial e de Empresa: Recuperação de Empresas, Falência e Procedimentos Concursais Administrativos. 11 ${ }^{\text {a }}$ Edição. São Paulo: Saraiva, 2017.

OLIVEIRA, Celso Marcelo de. Comentários à Nova Lei de Falências. São Paulo: Thomson IOB, 2010.

PAIVA, Luiz Fernando Valente de (coordenação). Direito Falimentar e a nova lei de falências e recuperação de empresas. Rio de Janeiro, Quartier Latin, 2005.

PERIN, Ecio Júnio. Curso de Direito Falimentar. $2^{\mathrm{a}}$ ed. rev., atual., e ampli., São Paulo: Método, 2004. 
PICOLO, Angelo Antonio. Natureza e limites do plano de recuperação de empresas (aspectos jurídicos e econômicos). Dissertação (Mestrado em Direito). Universidade de São Paulo, 2012.

PUGLIESI, Adriana Valéria. Direito Falimentar e Preservação da Empresa. Quartier Latin: São Paulo: 2013.

REQUIÃO, Rubens. Curso de Direito Falimentar: $2^{o}$ volume: Concordatas, crimes falimentares, intervenção e liquidação extrajudicial. 14a . ed., São Paulo: Saraiva, 1995.

RESTIFFE, Paulo Sérgio. Recuperação de empresas. Barueri; Manole: 2008.

RIBEIRO DIAS, Leonardo Adriano. Financiamento na Recuperação Judicial e na Falência. Quartier Latin: São Paulo: 2014.

RODRIGUES, Luiz Gustavo Friggi. Alcance da atuação judicial em sede de homologação do plano de recuperação judicial aprovado pela assembleia-geral de credores. Tese (Doutorado em Direito). Universidade Presbiteriana Mackenzie, 2014.

SACRAMONE, Marcelo Barbosa. Comentários à Lei de Recuperação de Empresas e Falência. São Paulo: Saraiva Educação, 2018.

SALLES, Daniel J. P. C., O controle judicial sobre a homologação do plano de recuperação judicial, in Revista de Direito Empresarial, ano 11, n. 1. Belo Horizonte: Editora Fórum, 2014.

SALOMÃO, Luis Felipe, Santos, Paulo Penalva. Recuperação judicial, extrajudicial e falência: teoria e prática. Forense: Rio de Janeiro, 2017.

SCALZILLI, João Pedro; SPINELLI, Luís Felipe, TELLECHEA, Rodrigo. Recuperação de Empresas e Falência: Teoria e Prática na Lei 11.101/2005. São Paulo: Almedina, 2016.

SILVA, Candice Buckley Bittencourt. A decisão de concessão da recuperação judicial - sua natureza e efeitos. Dissertação. (Mestrado em Direito). Pontifícia Universidade Católica de São Paulo, 2016. 
SIMIONATTO, Frederico Augusto Monte. Tratado de Direito Falimentar. Rio de Janeiro: Forense, 2008.

SOUZA NETTO, Antonio Evangelista. O Controle jurisdicional do plano de recuperação judicial: paradigma para o protagonismo cognoscitivo do Magistrado no exercício da Jurisdição. Tese (Doutorado em Direito). Pontifícia Universidade Católica de São Paulo, 2014.

TOMAZETTE, Marlon. Curso de direito empresarial, volume 3: falência e recuperação judicial. São Paulo: Atlas, 2016.

TOLEDO, Paulo Fernando de Campos Salles de (Coord.); ABRÃO, Carlos Henrique (Coord.). Comentários à Lei de Recuperação de Empresas e Falências. $4^{a}$ edição. São Paulo: Saraiva, 2016.

TOLEDO, Paulo Fernando de Campos Salles de (Coord.); SATIRO, Francisco (Coord.) Direito da Empresa em Crise: problemas e soluções. São Paulo: Quartier Latin, 2012.

TOLEDO, Paulo Fernando de Campo Salles de Toledo, O plano de recuperação e o controle judicial da legalidade, in Revista de Direito Bancário e do Mercado de Capitais, vol 60: São Paulo: Revista dos Tribunais, 2013.

TOLEDO, Paulo Fernando Campo Salles; e, PUGLIESI, Adriana V. Tratado de Direito Empresarial, volume V: Recuperação Empresarial e Falência. Coordenação CARVALHOSA, Modesto. São Paulo: Revista dos Tribunais, 2016.

VALVERDE, Trajano de Miranda. Comentários à Lei de Falências (Decreto-lei n ${ }^{\circ}$ 7.661, de 21 de junho de 1945). $2^{\text {a }}$ Edição. Revista Forense: Rio de Janeiro, 1955.

VALVERDE, Trajano de Miranda. Comentários à lei de falências: (Decreto-lei n. 7.661 de 21 de junho de 1945). $4^{\text {a }}$ ed. Rio de Janeiro: Forense, 1999. vol. 1. 
VAMPRÉ, Spencer. Tratado elementar de direito comercial, vol. I. Rio de Janeiro: F. Briguiet \& Cia. Editores, 1922.

VAZ, Janaína Campos Mesquita. Recuperação Judicial de Empresas: Atuação do juiz. Dissertação (Mestrado em Direito). Universidade de São Paulo, 2015. 


\section{ANEXO I - LISTA DE ACÓRDÃOS ANALISADOS}

\begin{tabular}{|c|c|c|}
\hline Tribunal: & Data de Julgamento: & Número do Recurso: \\
\hline $\begin{array}{l}\text { TJSP (Câmara Reservada à } \\
\text { Falência e Recuperação) }\end{array}$ & $10 / 08 / 10$ & $990.10 .111588-3$ \\
\hline $\begin{array}{l}\text { TJSP (Câmara Reservada à } \\
\text { Falência e Recuperação) }\end{array}$ & $01 / 02 / 11$ & 0372448-49.2010.8.26.0000 \\
\hline $\begin{array}{l}\text { TJSP (Câmara Reservada à } \\
\text { Falência e Recuperação) }\end{array}$ & $20 / 09 / 11$ & 0196402-74.2011.8.26.0000 \\
\hline $\begin{array}{l}\text { TJSP (Câmara Reservada à } \\
\text { Falência e Recuperação) }\end{array}$ & $28 / 02 / 12$ & 0136362-29.2011.8.26.0000 \\
\hline $\begin{array}{l}\text { TJSP ( } 1^{\text {a }} \text { Câmara Reservada de } \\
\text { Direito Empresarial) }\end{array}$ & $30 / 10 / 12$ & 0124832-91.2012.8.26.0000 \\
\hline $\begin{array}{l}\text { TJSP (1 }{ }^{\text {a }} \text { Câmara Reservada de } \\
\text { Direito Empresarial) }\end{array}$ & $30 / 10 / 12$ & 0071913-28.2012.8.26.0000 \\
\hline $\begin{array}{l}\text { TJSP ( } 1^{\text {a }} \text { Câmara Reservada de } \\
\text { Direito Empresarial) }\end{array}$ & $30 / 10 / 12$ & 0072149-77.2012.8.26.0000 \\
\hline $\begin{array}{l}\text { TJSP ( } 1^{\text {a }} \text { Câmara Reservada de } \\
\text { Direito Empresarial) }\end{array}$ & $30 / 10 / 12$ & 0124832-91.2012.8.26.0000 \\
\hline $\begin{array}{l}\text { TJSP ( } 1^{\text {a }} \text { Câmara Reservada de } \\
\text { Direito Empresarial) }\end{array}$ & $11 / 12 / 12$ & 0198440-25.2012.8.26.0000 \\
\hline $\begin{array}{l}\text { TJSP ( } 1^{\text {a }} \text { Câmara Reservada de } \\
\text { Direito Empresarial) }\end{array}$ & $26 / 03 / 13$ & 0099369-50.2012.8.26.0000 \\
\hline $\begin{array}{l}\text { TJSP ( } 1^{a} \text { Câmara Reservada de } \\
\text { Direito Empresarial) }\end{array}$ & $23 / 04 / 13$ & 0187811-89.2012.8.26.0000 \\
\hline $\begin{array}{l}\text { TJSP (2a Câmara Reservada de } \\
\text { Direito Empresarial) }\end{array}$ & $06 / 05 / 13$ & 0191819-12.2012.8.26.0000 \\
\hline $\begin{array}{l}\text { TJSP (2a Câmara Reservada de } \\
\text { Direito Empresarial) }\end{array}$ & $20 / 05 / 13$ & 0000707-17.2013.8.26.0000 \\
\hline $\begin{array}{l}\text { TJSP (2a Câmara Reservada de } \\
\text { Direito Empresarial) }\end{array}$ & $20 / 05 / 13$ & 0009544-61.2013.8.26.0000 \\
\hline $\begin{array}{l}\text { TJSP ( } 1^{\text {a }} \text { Câmara Reservada de } \\
\text { Direito Empresarial) }\end{array}$ & $13 / 06 / 13$ & 0067771-44.2013.8.26.0000 \\
\hline $\begin{array}{l}\text { TJSP ( } 1^{\text {a }} \text { Câmara Reservada de } \\
\text { Direito Empresarial) }\end{array}$ & $04 / 07 / 13$ & 0008634-34.2013.8.26.0000 \\
\hline $\begin{array}{l}\text { TJSP (2a Câmara Reservada de } \\
\text { Direito Empresarial) }\end{array}$ & $19 / 08 / 13$ & 0036314-91.2013.8.26.0000 \\
\hline $\begin{array}{l}\text { TJSP ( } 1^{\text {a }} \text { Câmara Reservada de } \\
\text { Direito Empresarial) }\end{array}$ & $29 / 08 / 13$ & 0103863-21.2013.8.26.0000 \\
\hline $\begin{array}{l}\text { TJSP ( } 1^{\text {a }} \text { Câmara Reservada de } \\
\text { Direito Empresarial) }\end{array}$ & $29 / 08 / 13$ & 0062115-09.2013.8.26.0000 \\
\hline $\begin{array}{l}\text { TJSP ( } 1^{\text {a }} \text { Câmara Reservada de } \\
\text { Direito Empresarial) }\end{array}$ & $12 / 09 / 13$ & 0076516-13.2013.8.26.0000 \\
\hline
\end{tabular}




\begin{tabular}{|c|c|c|}
\hline $\begin{array}{l}\text { TJSP ( } 2^{\mathrm{a}} \text { Câmara Reservada de } \\
\text { Direito Empresarial) }\end{array}$ & $30 / 09 / 13$ & 0275813-35.2012.8.26.0000 \\
\hline $\begin{array}{l}\text { TJSP ( } 2^{\mathrm{a}} \text { Câmara Reservada de } \\
\text { Direito Empresarial) }\end{array}$ & $04 / 11 / 13$ & 0009234-55.2013.8.26.0000 \\
\hline $\begin{array}{l}\text { TJSP ( } 2^{\text {a }} \text { Câmara Reservada de } \\
\text { Direito Empresarial) }\end{array}$ & $03 / 02 / 14$ & 0105481-98.2013.8.26.0000 \\
\hline $\begin{array}{l}\text { TJSP ( } 1^{\text {a }} \text { Câmara Reservada de } \\
\text { Direito Empresarial) }\end{array}$ & $06 / 02 / 14$ & 2023912-41.2013.8.26.0000 \\
\hline $\begin{array}{l}\text { TJSP (2 } 2^{\text {a }} \text { Câmara Reservada de } \\
\text { Direito Empresarial) }\end{array}$ & $17 / 03 / 14$ & 2024063-07.2013.8.26.0000 \\
\hline $\begin{array}{l}\text { TJSP ( } 1^{\text {a }} \text { Câmara Reservada de } \\
\text { Direito Empresarial) }\end{array}$ & $03 / 04 / 14$ & $0175314-43.2012 .8 .26 .0000$ \\
\hline $\begin{array}{l}\text { TJSP ( } 1^{\text {a }} \text { Câmara Reservada de } \\
\text { Direito Empresarial) }\end{array}$ & $03 / 04 / 14$ & 2017556-93.2014.8.26.0000 \\
\hline $\begin{array}{l}\text { TJSP ( } 2^{\mathrm{a}} \text { Câmara Reservada de } \\
\text { Direito Empresarial) }\end{array}$ & $14 / 04 / 14$ & 0136662-20.2013.8.26.0000 \\
\hline $\begin{array}{l}\text { TJSP ( } 1^{\text {a }} \text { Câmara Reservada de } \\
\text { Direito Empresarial) }\end{array}$ & $29 / 05 / 14$ & 0173522-20.2013.8.26.0000 \\
\hline $\begin{array}{l}\text { TJSP ( } 1^{\text {a }} \text { Câmara Reservada de } \\
\text { Direito Empresarial) }\end{array}$ & $03 / 07 / 14$ & 2084354-36.2014.8.26.0000 \\
\hline $\begin{array}{l}\text { TJSP ( } 1^{\text {a }} \text { Câmara Reservada de } \\
\text { Direito Empresarial) }\end{array}$ & 08/10/14 & 2126898-39.2014.8.26.0000 \\
\hline $\begin{array}{l}\text { TJSP ( } 1^{\text {a }} \text { Câmara Reservada de } \\
\text { Direito Empresarial) }\end{array}$ & 08/10/14 & 2032275-80.2014.8.26.0000 \\
\hline $\begin{array}{l}\text { TJSP ( } 2^{\mathrm{a}} \text { Câmara Reservada de } \\
\text { Direito Empresarial) }\end{array}$ & $17 / 11 / 14$ & 2050371-80.2013.8.26.0000 \\
\hline $\begin{array}{l}\text { TJSP ( } 1^{\text {a }} \text { Câmara Reservada de } \\
\text { Direito Empresarial) }\end{array}$ & $09 / 12 / 14$ & 2139325-68.2014.8.26.0000 \\
\hline $\begin{array}{l}\text { TJSP ( } 2^{\text {a }} \text { Câmara Reservada de } \\
\text { Direito Empresarial) }\end{array}$ & $10 / 12 / 14$ & 2129435-08.2014.8.26.0000 \\
\hline $\begin{array}{l}\text { TJSP ( } 1^{\text {a }} \text { Câmara Reservada de } \\
\text { Direito Empresarial) }\end{array}$ & $03 / 02 / 15$ & 2145354-37.2014.8.26.0000 \\
\hline $\begin{array}{l}\text { TJSP (2 } 2^{\mathrm{a}} \text { Câmara Reservada de } \\
\text { Direito Empresarial) }\end{array}$ & $10 / 04 / 15$ & 2157921-03.2014.8.26.0000 \\
\hline $\begin{array}{l}\text { TJSP ( } 2^{\mathrm{a}} \text { Câmara Reservada de } \\
\text { Direito Empresarial) }\end{array}$ & $10 / 04 / 15$ & 2123441-96.2014.8.26.0000 \\
\hline $\begin{array}{l}\text { TJSP ( } 1^{\text {a }} \text { Câmara Reservada de } \\
\text { Direito Empresarial) }\end{array}$ & $09 / 09 / 15$ & 2081350-54.2015.8.26.0000 \\
\hline $\begin{array}{l}\text { TJSP ( } 2^{\mathrm{a}} \text { Câmara Reservada de } \\
\text { Direito Empresarial) }\end{array}$ & $09 / 09 / 15$ & 2054977-83.2015.8.26.0000 \\
\hline $\begin{array}{l}\text { TJSP ( } 2^{\mathrm{a}} \text { Câmara Reservada de } \\
\text { Direito Empresarial) }\end{array}$ & $05 / 10 / 15$ & 2083154-57.2015.8.26.0000 \\
\hline $\begin{array}{l}\text { TJSP ( } 2^{\mathrm{a}} \text { Câmara Reservada de } \\
\text { Direito Empresarial) }\end{array}$ & $21 / 10 / 15$ & 2108870-86.2015.8.26.0000 \\
\hline $\begin{array}{l}\text { TJSP ( } 2^{\mathrm{a}} \text { Câmara Reservada de } \\
\text { Direito Empresarial) }\end{array}$ & $11 / 11 / 15$ & 2052325-30.2014.8.26.0000 \\
\hline $\begin{array}{l}\text { TJSP ( } 2^{\mathrm{a}} \text { Câmara Reservada de } \\
\text { Direito Empresarial) }\end{array}$ & $11 / 11 / 15$ & $2026150-62.2015 .8 .26 .0000$ \\
\hline
\end{tabular}




\begin{tabular}{|c|c|c|}
\hline $\begin{array}{l}\text { TJSP (2a Câmara Reservada de } \\
\text { Direito Empresarial) }\end{array}$ & $16 / 11 / 15$ & 2144508-83.2015.8.26.0000 \\
\hline $\begin{array}{l}\text { TJSP ( } 1^{\text {a }} \text { Câmara Reservada de } \\
\text { Direito Empresarial) }\end{array}$ & $16 / 03 / 16$ & 2185033-10.2015.8.26.0000 \\
\hline $\begin{array}{l}\text { TJSP ( } 1^{\text {a }} \text { Câmara Reservada de } \\
\text { Direito Empresarial) }\end{array}$ & $16 / 03 / 16$ & 2186269-94.2015.8.26.0000 \\
\hline $\begin{array}{l}\text { TJSP ( } 1^{\text {a }} \text { Câmara Reservada de } \\
\text { Direito Empresarial) }\end{array}$ & $20 / 04 / 16$ & 2249187-37.2015.8.26.0000 \\
\hline $\begin{array}{l}\text { TJSP (2a Câmara Reservada de } \\
\text { Direito Empresarial) }\end{array}$ & $27 / 04 / 16$ & 2108281-94.2015.8.26.0000 \\
\hline $\begin{array}{l}\text { TJSP (2a Câmara Reservada de } \\
\text { Direito Empresarial) }\end{array}$ & $11 / 05 / 16$ & $2261874-46.2015 .8 .26 .0000$ \\
\hline $\begin{array}{l}\text { TJSP (1 }{ }^{\text {a }} \text { Câmara Reservada de } \\
\text { Direito Empresarial) }\end{array}$ & $18 / 05 / 16$ & 2000664-41.2016.8.26.0000 \\
\hline $\begin{array}{l}\text { TJSP (2a Câmara Reservada de } \\
\text { Direito Empresarial) }\end{array}$ & $25 / 05 / 16$ & 2201557-82.2015.8.26.0000 \\
\hline $\begin{array}{l}\text { TJSP (2a Câmara Reservada de } \\
\text { Direito Empresarial) }\end{array}$ & $25 / 05 / 16$ & 2230018-64.2015.8.26.0000 \\
\hline $\begin{array}{l}\text { TJSP ( } 1^{\text {a }} \text { Câmara Reservada de } \\
\text { Direito Empresarial) }\end{array}$ & $22 / 06 / 16$ & 2022593-33.2016.8.26.0000 \\
\hline $\begin{array}{l}\text { TJSP ( } 2^{\mathrm{a}} \text { Câmara Reservada de } \\
\text { Direito Empresarial) }\end{array}$ & $27 / 06 / 16$ & 2011357-84.2016.8.26.0000 \\
\hline $\begin{array}{l}\text { TJSP ( } 1^{\text {a }} \text { Câmara Reservada de } \\
\text { Direito Empresarial) }\end{array}$ & $13 / 07 / 16$ & 205355-67.2016.8.26.0000 \\
\hline $\begin{array}{l}\text { TJSP (2a Câmara Reservada de } \\
\text { Direito Empresarial) }\end{array}$ & $15 / 08 / 16$ & 2051678-64.2016.8.26.0000 \\
\hline $\begin{array}{l}\text { TJSP (1 }{ }^{\text {a }} \text { Câmara Reservada de } \\
\text { Direito Empresarial) }\end{array}$ & $19 / 09 / 16$ & 2266815-39.2015.8.26.0000 \\
\hline $\begin{array}{l}\text { TJSP (1 }{ }^{\text {a }} \text { Câmara Reservada de } \\
\text { Direito Empresarial) }\end{array}$ & $21 / 09 / 16$ & 2112611-03.2016.8.26.0000 \\
\hline $\begin{array}{l}\text { TJSP ( } 1^{\text {a }} \text { Câmara Reservada de } \\
\text { Direito Empresarial) }\end{array}$ & 19/10/16 & 2084564-19.2016.8.26.0000 \\
\hline $\begin{array}{l}\text { TJSP (2a Câmara Reservada de } \\
\text { Direito Empresarial) }\end{array}$ & $31 / 10 / 16$ & 1040831-03.2016.8.26.000 \\
\hline $\begin{array}{l}\text { TJSP ( } 1^{a} \text { Câmara Reservada de } \\
\text { Direito Empresarial) }\end{array}$ & $09 / 11 / 16$ & 2095152-85.2016.8.26.0000 \\
\hline $\begin{array}{l}\text { TJSP (2a Câmara Reservada de } \\
\text { Direito Empresarial) }\end{array}$ & $28 / 11 / 16$ & 2263007-26.2015.8.26.0000 \\
\hline $\begin{array}{l}\text { TJSP (2a Câmara Reservada de } \\
\text { Direito Empresarial) }\end{array}$ & $28 / 11 / 16$ & 2262669-52.2015.8.26.0000 \\
\hline $\begin{array}{l}\text { TJSP ( } 1^{\text {a }} \text { Câmara Reservada de } \\
\text { Direito Empresarial) }\end{array}$ & $07 / 12 / 16$ & 2178688-91.2016.8.26.0000 \\
\hline $\begin{array}{l}\text { TJSP (1 }{ }^{\text {a }} \text { Câmara Reservada de } \\
\text { Direito Empresarial) }\end{array}$ & $12 / 01 / 17$ & 2187753-13.2016.8.26.0000 \\
\hline $\begin{array}{l}\text { TJSP ( } 1^{\text {a }} \text { Câmara Reservada de } \\
\text { Direito Empresarial) }\end{array}$ & $08 / 02 / 17$ & 2176237-93.2016.8.26.0000 \\
\hline $\begin{array}{l}\text { TJSP (2a Câmara Reservada de } \\
\text { Direito Empresarial) }\end{array}$ & $13 / 02 / 17$ & 2014604-73.2016.8.26.0000 \\
\hline
\end{tabular}




\begin{tabular}{|c|c|c|}
\hline $\begin{array}{l}\text { TJSP ( } 2^{\text {a }} \text { Câmara Reservada de } \\
\text { Direito Empresarial) }\end{array}$ & $24 / 02 / 17$ & 2122098-94.2016.8.26.0000 \\
\hline $\begin{array}{l}\text { TJSP ( } 2^{\text {a }} \text { Câmara Reservada de } \\
\text { Direito Empresarial) }\end{array}$ & $13 / 03 / 17$ & 2102479-81.2016.8.26.0000 \\
\hline $\begin{array}{l}\text { TJSP ( } 2^{\text {a }} \text { Câmara Reservada de } \\
\text { Direito Empresarial) }\end{array}$ & $27 / 03 / 17$ & 2185286-62.2016.8.26.0000 \\
\hline $\begin{array}{l}\text { TJSP ( } 2^{\text {a }} \text { Câmara Reservada de } \\
\text { Direito Empresarial) }\end{array}$ & $10 / 04 / 17$ & 2162922-95.2016.8.26.0000 \\
\hline $\begin{array}{l}\text { TJSP ( } 1^{\text {a }} \text { Câmara Reservada de } \\
\text { Direito Empresarial) }\end{array}$ & 09/06/17 & 2242949-65.2016.8.26.0000 \\
\hline $\begin{array}{l}\text { TJSP ( } 1^{\text {a }} \text { Câmara Reservada de } \\
\text { Direito Empresarial) }\end{array}$ & $16 / 08 / 17$ & 2044370-40.2017.8.26.0000 \\
\hline $\begin{array}{l}\text { TJSP ( } 2^{\text {a }} \text { Câmara Reservada de } \\
\text { Direito Empresarial) }\end{array}$ & $18 / 08 / 17$ & 2080153-93.2017.8.26.0000 \\
\hline $\begin{array}{l}\text { TJSP ( } 2^{\text {a }} \text { Câmara Reservada de } \\
\text { Direito Empresarial) }\end{array}$ & $24 / 08 / 17$ & 2069907-38.2017.8.26.0000 \\
\hline $\begin{array}{l}\text { TJSP ( } 2^{\text {a }} \text { Câmara Reservada de } \\
\text { Direito Empresarial) }\end{array}$ & $31 / 08 / 17$ & $2241107-50.2016 .8 .26 .0000$ \\
\hline $\begin{array}{l}\text { TJSP ( } 1^{\text {a }} \text { Câmara Reservada de } \\
\text { Direito Empresarial) }\end{array}$ & $13 / 09 / 17$ & 2062583-94.2017.8.26.0000 \\
\hline $\begin{array}{l}\text { TJSP ( } 2^{\text {a }} \text { Câmara Reservada de } \\
\text { Direito Empresarial) }\end{array}$ & $25 / 09 / 17$ & 2243739-49.2016.8.26.0000 \\
\hline $\begin{array}{l}\text { TJSP (2 } 2^{\text {a }} \text { Camara Reservada de } \\
\text { Direito Empresarial) }\end{array}$ & $02 / 10 / 17$ & 2042945-75.2017.8.26.0000 \\
\hline $\begin{array}{l}\text { TJSP ( } 2^{\text {a }} \text { Câmara Reservada de } \\
\text { Direito Empresarial) }\end{array}$ & $01 / 11 / 17$ & 2129292-14.2017.8.26.0000 \\
\hline $\begin{array}{l}\text { TJSP ( } 1^{\text {a }} \text { Câmara Reservada de } \\
\text { Direito Empresarial) }\end{array}$ & $08 / 11 / 17$ & 2162016-71.2017.8.26.0000 \\
\hline $\begin{array}{l}\text { TJSP ( } 2^{\text {a }} \text { Câmara Reservada de } \\
\text { Direito Empresarial) }\end{array}$ & $13 / 11 / 17$ & 2124309-69.2017.8.26.0000 \\
\hline $\begin{array}{l}\text { TJSP ( } 2^{\text {a }} \text { Câmara Reservada de } \\
\text { Direito Empresarial) }\end{array}$ & $27 / 11 / 17$ & 2131912-96.2017.8.26.0000 \\
\hline $\begin{array}{l}\text { TJSP ( } 1^{\text {a }} \text { Câmara Reservada de } \\
\text { Direito Empresarial) }\end{array}$ & $29 / 11 / 17$ & 2071301-80.2017.8.26.0000 \\
\hline $\begin{array}{l}\text { TJSP ( } 2^{a} \text { Câmara Reservada de } \\
\text { Direito Empresarial) }\end{array}$ & $11 / 12 / 17$ & 2174438-78.2017.8.26.0000 \\
\hline $\begin{array}{l}\text { TJSP (2 } 2^{\text {a }} \text { Camara Reservada de } \\
\text { Direito Empresarial) }\end{array}$ & $11 / 12 / 17$ & 2002256-86.2017.8.26.0000 \\
\hline $\begin{array}{l}\text { TJSP (2 }{ }^{\text {a }} \text { Camara Reservada de } \\
\text { Direito Empresarial) }\end{array}$ & $11 / 12 / 17$ & 2179940-95.2017.8.26.0000 \\
\hline $\begin{array}{l}\text { TJSP ( } 1^{\text {a }} \text { Câmara Reservada de } \\
\text { Direito Empresarial) }\end{array}$ & $13 / 12 / 17$ & 2113789-50.2017.8.26.0000 \\
\hline $\begin{array}{l}\text { TJSP ( } 2^{\text {a }} \text { Câmara Reservada de } \\
\text { Direito Empresarial) }\end{array}$ & $15 / 12 / 17$ & 21809666-31.2017.8.26.0000 \\
\hline $\begin{array}{l}\text { TJSP ( } 2^{\text {a }} \text { Câmara Reservada de } \\
\text { Direito Empresarial) }\end{array}$ & $18 / 12 / 17$ & 2167579-46.2017.8.26.0000 \\
\hline $\begin{array}{l}\text { TJSP ( } 2^{\text {a }} \text { Câmara Reservada de } \\
\text { Direito Empresarial) }\end{array}$ & $18 / 12 / 17$ & $2098842-88.2017 .8 .26 .0000$ \\
\hline $\begin{array}{l}\text { TJSP ( } 2^{\text {a }} \text { Câmara Reservada de } \\
\text { Direito Empresarial) }\end{array}$ & $30 / 01 / 18$ & $2134322-30.2017 .8 .26 .0000$ \\
\hline $\begin{array}{l}\text { TJSP ( } 1^{\text {a }} \text { Câmara Reservada de } \\
\text { Direito Empresarial) }\end{array}$ & $19 / 02 / 18$ & 2192966-63.2017.8.26.0000 \\
\hline $\begin{array}{l}\text { TJSP ( } 2^{\text {a }} \text { Câmara Reservada de } \\
\text { Direito Empresarial) }\end{array}$ & $26 / 02 / 18$ & $2124944-50.2017 .8 .26 .0000$ \\
\hline $\begin{array}{l}\text { TJSP ( } 2^{\text {a }} \text { Câmara Reservada de } \\
\text { Direito Empresarial) }\end{array}$ & $27 / 02 / 18$ & 2108934-28.2017.8.26.0000 \\
\hline $\begin{array}{l}\text { TJSP ( } 1^{\text {a }} \text { Câmara Reservada de } \\
\text { Direito Empresarial) }\end{array}$ & $27 / 02 / 18$ & $2199053-35.2017 .8 .26 .0000$ \\
\hline
\end{tabular}




\begin{tabular}{|c|c|c|}
\hline $\begin{array}{l}\text { TJSP ( } 2^{\text {a }} \text { Câmara Reservada de } \\
\text { Direito Empresarial) }\end{array}$ & $12 / 03 / 18$ & 2179122-46.2017.8.26.0000 \\
\hline $\begin{array}{l}\text { TJSP ( } 2^{\mathrm{a}} \text { Câmara Reservada de } \\
\text { Direito Empresarial) }\end{array}$ & $26 / 03 / 18$ & 2136702-26.2017.8.26.0000 \\
\hline $\begin{array}{l}\text { TJSP ( } 2^{\mathrm{a}} \text { Câmara Reservada de } \\
\text { Direito Empresarial) }\end{array}$ & $10 / 04 / 18$ & 2197967-29.2017.8.26.0000 \\
\hline $\begin{array}{l}\text { TJSP ( } 2^{\mathrm{a}} \text { Câmara Reservada de } \\
\text { Direito Empresarial) }\end{array}$ & $16 / 04 / 18$ & $2207033-33.2017 .8 .26 .0000$ \\
\hline $\begin{array}{l}\text { TJSP ( } 1^{\text {a }} \text { Câmara Reservada de } \\
\text { Direito Empresarial) }\end{array}$ & $25 / 04 / 18$ & 21464956-09.2017.8.26.0000 \\
\hline $\begin{array}{l}\text { TJSP ( } 1^{\text {a }} \text { Câmara Reservada de } \\
\text { Direito Empresarial) }\end{array}$ & $02 / 05 / 18$ & $2238165-11.2017 .8 .26 .0000$ \\
\hline $\begin{array}{l}\text { TJSP ( } 2^{\mathrm{a}} \text { Câmara Reservada de } \\
\text { Direito Empresarial) }\end{array}$ & $15 / 05 / 18$ & 2001561-98.2018.8.26.0000 \\
\hline $\begin{array}{l}\text { TJSP ( } 1^{\text {a }} \text { Câmara Reservada de } \\
\text { Direito Empresarial) }\end{array}$ & $17 / 05 / 18$ & 2050737-46.2018.8.26.0000 \\
\hline $\begin{array}{l}\text { TJSP ( } 2^{\mathrm{a}} \text { Câmara Reservada de } \\
\text { Direito Empresarial) }\end{array}$ & $21 / 05 / 18$ & $2117412-25.2017 .8 .26 .0000$ \\
\hline $\begin{array}{l}\text { TJSP ( } 2^{\mathrm{a}} \text { Câmara Reservada de } \\
\text { Direito Empresarial) }\end{array}$ & $23 / 05 / 18$ & $2226968-59.2017 .8 .26 .0000$ \\
\hline $\begin{array}{l}\text { TJSP ( } 2^{\mathrm{a}} \text { Câmara Reservada de } \\
\text { Direito Empresarial) }\end{array}$ & $28 / 05 / 18$ & $2245698-55.2016 .8 .26 .0000$ \\
\hline $\begin{array}{l}\text { TJSP ( } 2^{\text {a }} \text { Câmara Reservada de } \\
\text { Direito Empresarial) }\end{array}$ & $28 / 05 / 18$ & 2239471-49.2016.8.26.0000 \\
\hline $\begin{array}{l}\text { TJSP ( } 1^{\text {a }} \text { Câmara Reservada de } \\
\text { Direito Empresarial) }\end{array}$ & $30 / 05 / 18$ & 2002134-39.2018.8.26.0000 \\
\hline $\begin{array}{l}\text { TJSP ( } 1^{\text {a }} \text { Câmara Reservada de } \\
\text { Direito Empresarial) }\end{array}$ & $06 / 06 / 18$ & $2110365-63.2018 .8 .26 .0000$ \\
\hline $\begin{array}{l}\text { TJSP ( } 2^{\text {a }} \text { Câmara Reservada de } \\
\text { Direito Empresarial) }\end{array}$ & $18 / 06 / 18$ & $2131456-49.2017 .8 .26 .0000$ \\
\hline $\begin{array}{l}\text { TJSP ( } 1^{\text {a }} \text { Câmara Reservada de } \\
\text { Direito Empresarial) }\end{array}$ & $20 / 07 / 18$ & 2213062-02-2017.8.26.0000 \\
\hline $\begin{array}{l}\text { TJSP ( } 2^{\text {a }} \text { Câmara Reservada de } \\
\text { Direito Empresarial) }\end{array}$ & $24 / 07 / 18$ & 2061773-85.2018.8.26.0000 \\
\hline $\begin{array}{l}\text { TJSP ( } 1^{\text {a }} \text { Câmara Reservada de } \\
\text { Direito Empresarial) }\end{array}$ & $25 / 07 / 18$ & $2116508-68.2018 .8 .26 .0000$ \\
\hline $\begin{array}{l}\text { TJSP ( } 2^{\mathrm{a}} \text { Câmara Reservada de } \\
\text { Direito Empresarial) }\end{array}$ & $26 / 07 / 18$ & 2006466-49.2018.8.26.0000 \\
\hline $\begin{array}{l}\text { TJSP ( } 1^{\text {a }} \text { Câmara Reservada de } \\
\text { Direito Empresarial) }\end{array}$ & $30 / 07 / 18$ & $2119415-26.2018 .8 .26 .0000$ \\
\hline $\begin{array}{l}\text { TJSP ( } 2^{\mathrm{a}} \text { Câmara Reservada de } \\
\text { Direito Empresarial) }\end{array}$ & $30 / 07 / 18$ & 2103254-43.2018.8.26.0000 \\
\hline $\begin{array}{l}\text { TJSP ( } 2^{\mathrm{a}} \text { Câmara Reservada de } \\
\text { Direito Empresarial) }\end{array}$ & $30 / 07 / 18$ & 2097656-93.2018.8.26.0000 \\
\hline $\begin{array}{l}\text { TJSP ( } 2^{\mathrm{a}} \text { Câmara Reservada de } \\
\text { Direito Empresarial) }\end{array}$ & $30 / 07 / 18$ & 2013198-46.2018.8.26.0000 \\
\hline $\begin{array}{l}\text { TJSP ( } 1^{\text {a }} \text { Câmara Reservada de } \\
\text { Direito Empresarial) }\end{array}$ & 03/08/18 & 2064888-17.2018.8.26.0000 \\
\hline $\begin{array}{l}\text { TJSP ( } 2^{\mathrm{a}} \text { Câmara Reservada de } \\
\text { Direito Empresarial) }\end{array}$ & 08/08/18 & $2211510-02.2017 .8 .26 .0000$ \\
\hline $\begin{array}{l}\text { TJSP ( } 2^{\mathrm{a}} \text { Câmara Reservada de } \\
\text { Direito Empresarial) }\end{array}$ & 08/08/18 & $2211510-02.2017 .8 .26 .0000$ \\
\hline $\begin{array}{l}\text { TJSP ( } 2^{\mathrm{a}} \text { Câmara Reservada de } \\
\text { Direito Empresarial) }\end{array}$ & 08/08/18 & 2052606-78.20178.26.0000 \\
\hline $\begin{array}{l}\text { TJSP ( } 1^{\text {a }} \text { Câmara Reservada de } \\
\text { Direito Empresarial) }\end{array}$ & 08/08/18 & $2038011-40.2018 .8 .26 .0000$ \\
\hline
\end{tabular}




\begin{tabular}{|c|c|c|}
\hline $\begin{array}{l}\text { TJSP ( }{ }^{\text {a }} \text { Câmara Reservada de } \\
\text { Direito Empresarial) }\end{array}$ & $17 / 08 / 18$ & $2130520-87.2018 .8 .26 .0000$ \\
\hline $\begin{array}{l}\text { TJSP (2 }{ }^{\text {a }} \text { Câmara Reservada de } \\
\text { Direito Empresarial) }\end{array}$ & $24 / 08 / 18$ & 2119532-07.2018.8.26.0000 \\
\hline $\begin{array}{l}\text { TJSP (2 }{ }^{\text {a }} \text { Câmara Reservada de } \\
\text { Direito Empresarial) }\end{array}$ & $27 / 08 / 18$ & 2138467-95.2018.8.26.0000 \\
\hline $\begin{array}{l}\text { TJSP (2 }{ }^{a} \text { Câmara Reservada de } \\
\text { Direito Empresarial) }\end{array}$ & $27 / 08 / 18$ & 2107096-16.2018.8.26.0000 \\
\hline $\begin{array}{l}\text { TJSP (2 }{ }^{\text {a }} \text { Câmara Reservada de } \\
\text { Direito Empresarial) }\end{array}$ & $28 / 08 / 18$ & $2140287-52.2018 .8 .26 .0000$ \\
\hline $\begin{array}{l}\text { TJSP (2 }{ }^{\text {a }} \text { Câmara Reservada de } \\
\text { Direito Empresarial) }\end{array}$ & $31 / 08 / 18$ & 2130207-29.2018.8.26.0000 \\
\hline $\begin{array}{l}\text { TJSP (2 }{ }^{\text {a }} \text { Câmara Reservada de } \\
\text { Direito Empresarial) }\end{array}$ & $31 / 08 / 18$ & 2085934-62.2018.8.26.0000 \\
\hline $\begin{array}{l}\text { TJSP (2 }{ }^{\text {a }} \text { Câmara Reservada de } \\
\text { Direito Empresarial) }\end{array}$ & $10 / 09 / 18$ & 2086061-97.2018.8.26.0000 \\
\hline $\begin{array}{l}\text { TJSP ( } 1^{\text {a }} \text { Câmara Reservada de } \\
\text { Direito Empresarial) }\end{array}$ & $13 / 09 / 18$ & $2079455-53.2018 .8 .26 .0000$ \\
\hline $\begin{array}{l}\text { TJSP (2 }{ }^{\text {a }} \text { Câmara Reservada de } \\
\text { Direito Empresarial) }\end{array}$ & $14 / 09 / 18$ & $2049571-76.2018 .8 .26 .0000$ \\
\hline $\begin{array}{l}\text { TJSP (2 }{ }^{\text {a }} \text { Câmara Reservada de } \\
\text { Direito Empresarial) }\end{array}$ & $17 / 09 / 18$ & $2085465-16.2018 .8 .26 .0000$ \\
\hline $\begin{array}{l}\text { TJSP ( } 2^{a} \text { Câmara Reservada de } \\
\text { Direito Empresarial) }\end{array}$ & $17 / 09 / 18$ & $2057365-51.2018 .8 .26 .0000$ \\
\hline $\begin{array}{l}\text { TJSP ( } 2^{\mathrm{a}} \text { Câmara Reservada de } \\
\text { Direito Empresarial) }\end{array}$ & $24 / 09 / 18$ & $2147690-72.2018 .8 .26 .0000$ \\
\hline $\begin{array}{l}\text { TJSP ( } 2^{\mathrm{a}} \text { Câmara Reservada de } \\
\text { Direito Empresarial) }\end{array}$ & $17 / 10 / 18$ & 2081908-89.2016.8.26.0000 \\
\hline $\begin{array}{l}\text { TJSP ( } 2^{\mathrm{a}} \text { Câmara Reservada de } \\
\text { Direito Empresarial) }\end{array}$ & $31 / 10 / 18$ & 2099546-38.2016.8.26.0000 \\
\hline
\end{tabular}

